\title{
Editorial
}

\section{WELCOME ON BOARD: ANNALS OF MEDITERRANEAN SURGERY}

\author{
Francesc Xavier González Argenté ${ }^{1}$ \\ ${ }^{1}$ Corresponding author. Department of General Surgery, Hospital Universitario Son Espases. \\ Ctra. De Valldemossa 79, Balearic Islands, Palma de Mallorca, 07010. Spain. Phone: 0034-871205000. \\ E-mail address: xavier.gonzalez@ssib.es
}

\section{Dear partners,}

It is a great pleasure to present the first issue of our journal "Annals of Mediterranean Surgery" (AMS), the official written organ of the Balearic Society of Surgery (SOBACIR).

The main objective of the journal is contributing to the dissemination of medical research with special focus on surgical disciplines, aimed at medical professionals, researchers, students, teachers and all those who are interested in our field of study.

We have the illusion of growing and being able to become an international scientific journal that in the future can be indexed and included en the best bibliographic indexes. For this, we will have the collaboration of surgeons of national and international prestige that will form the editorial committee and the team of reviewers.

The important impact of the digital revolution on the scientific publishing industry makes us opt for a digital formal with an open and free access system, which will allow the transfer of knowledge with demanding quality criteria. For this we rely on the collaboration of recognized experts and the evaluation through an external anonymous process of peer review.

To meet these objectives we need and we ask the collaboration of the members of the Balearic Society of Surgery to send us articles of the highest quality and interest for its application in daily practice of which we feel surgeons.

We are in the era of immediate communication and the magazine should take advantage of social networks to promote the dissemination of scientific knowledge. I am sure that you will incorporate it into the already dynamic activity that you have within the social networks.

We trust that can arouse your interest and we invite you to participate en the next issues.

Editor in Chief

F. Xavier González Argenté 


\section{WELCOME ON BOARD: ANNALS OF MEDITERRANEAN SURGERY}

\section{Francesc Xavier González Argenté ${ }^{1}$}

${ }^{1}$ Corresponding author. Department of General Surgery, Hospital Universitario Son Espases.

Ctra. De Valldemossa 79, Balearic Islands, Palma de Mallorca, 07010. Spain. Phone: 0034-871205000.

E-mail address: xavier.gonzalez@ssib.es

\section{Estimados compañeros,}

Es un gran placer presentar el primer número de la revista "Annals of Mediterranean Surgery" (AMS) como el órgano oficial escrito de la Sociedad Balear de Cirugía (SOBACIR).

El objetivo principal de la revista es contribuir a la difusión de la investigación médica con especial enfoque en las disciplinas quirúrgicas, dirigido a los profesionales médicos, comunidad de investigadores, estudiantes, docentes y todos aquellos que estén interesados en nuestro ámbito de estudio.

Tenemos la ilusión de crecer y poder llegar a ser una revista científica internacional que en el futuro pueda indexarse y estar incluida en los mejores índices bibliográficos. Para ello, contaremos con la colaboración de cirujanos de prestigio nacional e internacional que formaran el comité editorial y el equipo de revisores.

El importante impacto de la revolución digital sobre la industria editorial científica nos hace que optemos por un formato digital con un sistema de acceso abierto y gratuito, que permitirá la transferencia de conocimientos con unos exigentes criterios de calidad. Para ello contamos con la colaboración de reconocidos expertos y la valoración mediante un proceso anónimo externo de revisión por pares.

Para cumplir con estos objetivos necesitamos y os pedimos la colaboración de los miembros de la Sociedad Balear de Cirugía para que nos remitáis artículos de la mayor calidad e interés para su aplicación en la práctica diaria de los que nos sentimos cirujanos.

Estamos en la era de la comunicación inmediata y la revista debe aprovechar las redes sociales para favorecer la difusión de los conocimientos científicos. Estoy seguro que la incorporareis a la ya dinámica actividad que tenéis dentro de las redes sociales.

Confiamos en que podamos suscitar vuestro interés y os invitamos a participar en los próximos números.

Editor in Chief

F. Xavier González Argenté 